\title{
Study on the Problems and Countermeasures of the Students' Ideological and Political Education of Private Colleges
}

\author{
Yao Li \\ Huanghe Science \& Technology College, Zhengzhou, China \\ wxkbbg@163.com
}

Keywords: Private colleges; Students; Ideological and political education; Countermeasure

\begin{abstract}
With the continuous improvement education system, private education has been rapid development in recent years; the students' ideological and political education of private college has become an important part of quality education which needs greatly strengthening and improving. The students' ideological and political education of private colleges has the problems of the imperfect system, the unreasonable teacher's structure, lack of innovation mechanisms and the poor combination both from the locality and from abroad. So we put forward some countermeasures and solutions to change ideas, reform and innovation, and create a good ideological and political education environment, further to enhance the effectiveness and relevance of the students' ideological and political education in the private colleges.
\end{abstract}

\section{民办高校学生思想政治教育存在问题及对策研究}

\author{
李耀 \\ 黄河科技学院, 郑州 中国
}

摘要: 随着教育机制不断完善, 民办教育近年来得到了突飞猛进的发展, 加强和改进民办高 校学生的思想政治教育也成为我国素质教育的一个重要环节。针对当前民办高校学生思想政 治教育存在制度不完善、师资队伍不合理、机制创新不足和内外合力差等问题, 提出了一些 了解决的对策和方法, 来转变观念、改革创新、营造良好思想政治教育环境, 增强民办高校 学生思想政治教育工作实效性和针对性。

关键词：民办高校; 学生; 思想政治教育; 对策

\section{前言}

民办高校是中国特色社会主义教育事业的重要组成部分。《国家中长期教育改革和发展规划纲 要 (2010-2020 年) 》中明确指出, 要大力支持民办教育, 支持民办学校创新管理机制和育 人模式, 提高质量, 办出特色, 办好一批高水平民办学校。在 2013 年全国教育工作会议上, 教育部部长袁贵仁指出, 要重点支持民办教育的发展, 全面清理针对民办教育的各种歧视政 策。民办高校思想政治工作对民办高校坚持社会主义办学方向，贯彻党和国家教育方针，保 证教育教学质量都具有十分重要的意义。因此, 调查研究民办高校思想政治工作现状, 发现 其凸显的优点和问题, 进一步发扬优点, 解决客观存在的现实问题, 是提升大学生思想政治 素养的需要, 也是民办高校长足发展的需要。

\section{1. 加强民办教育学生思想政治工作的重要性}

加强民办高校学生思想政治教育是我国社会主义教育事业的需要。民办高校作为我国教育事 业的重要组成部分, 是我国教育事业的重要支柱, 应该坚持党和国家的教育制度的指导方针 和政策，遵循社会主义事业的发展方向，为我国的社会建设培养思想优秀的建设者和保卫者。 加强思想政治教育是民办高效培养目标的重要要求。思想政治教育体现了学生的思想道德水 
平和个人文化修养水平, 是其思想觉悟的重要表现层次, 有利于提高个人修养, 树立正确的 价值观、人生观、世界观。加强学生思想政治教育有利于民办高校的可持续发展, 有利于引 导学生正确认识民主法制建设, 树立正确的平等自由意识, 从而实现国家的长治久安, 实现 中国梦的伟大目标。

\section{2. 民办高校学生思想政治教育的现状及存在的问题}

\section{1. 民办高校思想政治教育制度不完善}

国家鼓励教育事业发展的同时也带来了相应的弊端, 随着民办高校数量的不断增多, 大学生 就业压力也随之而来。面临这种严峻问题, 大学生的思想政治难以适应时代的发展, 这使得 高校原有的传统思想政治教育体制面临严峻挑战, 从而导致学校的思想政治教育文化氛围不 高, 大学生的思想政治觉悟低下, 从而影响了学生、高校和社会的发展。

2.2. 思想政治教育的师资队伍不完善

思想政治教育工作队伍是加强和改进大学生思想政治教育的组织保证, 是思想政治教育取得 成效的关键。由于种种原因民办院校不可避免的存在只重视学院规模的发展, 而对内涵发展 和学生思想政治教育工作不够重视的问题, 党团组织不完善, 对学生的影响不大。表现在入 党的积极性不高、动机和目的不明确, 对党、对国家、对集体认识不深刻, 导致部分学生爱 国主义、集体主义淡漠，没有服务社会的意识。

大学生思想政治教育工作队伍主体是学校党政干部和共青团干部, 思想政治理论课和哲学社 会科学课教师, 辅导员和班主任。当前, 一个不争的事实是, 在思想政治教育工作队伍建设 方面，民办高校力度相对不足。

很多民办高校还处于快速发展和上升阶段, 对学校的基础设施的投入较大, 加之, 学校的教 师流动性较大, 从而忽视了对思想政治教育的师资队伍建设。思想政治教育缺乏规范性管理 模式, 辅导员自身素质技能不过硬, 缺少专业性的培训, 无法有针对性地对学生进行管理教 育。

2.3. 思想政治教育机制缺乏创新性

传统的思想政治教育机制主要是通过开会、座谈、上课等形式来表现的, 缺乏创新机制, 无 法吸引学生, 使学生无法发挥主观能动性。其次, 传统的教育机制中学生数量较多, 教师无 法做到面面俱到, 缺乏专业性的指导教育机构, 导致民办高校大学生的思想问题及解决方式 缺乏专门的研究, 从而影响学生的思想政治教育的发展。最后, 信息反馈机制流通不畅, 导 致信息在学生、家长和学校三方中无法贯彻和落实。

2.4. 思想政治教育难以与社会环境 、家庭教育形成校外合力

由于大学生思想品德的形成和发展既受到客观外界条件的影响, 又受到主观内部因素的制约, 因此, 只有当家庭、社区、各种群众组织和团体、各种信息传播媒介以不同的方式对受教育 者发生的作用与社会发展方向和教育目标相一致时, 才能形成合力, 促进受教育者的思想品 德的发展, 否则, 就会抵消学校教育的成果。而事实上, 学校教育工作目前最大的难题就是 很难与社会环境、家庭教育形成合力。

2.5. 思想政治教育没有形成校内合力

思想政治教育的特殊性就在于它不是简单的知识传授, 而主要是依靠周围环境的熏陶和感染, 因此, 思想政治教育必须和日常的业务与管理工作一起来开展, 渗透到学校生活的全过程中 去。然而，在民办高校，能做到这一点的并不多见。尤其表现在以下几个方面：

（1）思想政治理论课教学与日常教育相脱节。（2）思想政治教育与专业教育相脱节。（3）思 想政治教育与学校管理工作相脱节。

综上所述, 民办高校与其员工之间的 “雇佣关系”, 使得教职工往往存在严重的 “打工心理”, 再加上他们对思想政治教育认识上的不到位，使得民办高校的思想政治教育几乎完全成了思 想政治理论课教师或辅导员的任务, 而这些教师又疲于应付繁重的教学工作或行政工作, 致 使学校的思想政治教育成了 “空对空”。 


\section{3. 解决我国民办高校学生思想政治教育问题的对策与建议}

\section{1. 提高认识, 纠正和更新传统观念}

针对当前存在的突出问题, 深入开展专题研讨, 提高对加强和改进民办高校学生思想政治教 育重要性和必要性的认识, 把思想统一到中央关于加强和改进大学生思想政治教育的要求上 来。牢固树立思想政治教育工作是民办高校生存与发展的生命线, 要始终坚持教书育人、育 人为本，德智体美、德育为首的观念。充分发挥高校思想政治教育的政治导向、思想导向、 舆论导向、文化导向、环境导向作用，强化民办高校教育观念，强化开放式教育的观念，努 力推进思想政治教育工作创新。

3.2. 加强民办高校的思想政治氛围建设

学校党组织对学生思想政治教育工作负有领导责任, 要充分发挥政治核心作用, 把师德建设 和学生思想政治教育作为重要职责, 教育广大党员教师发挥先锋模范作用。民办高校党组织 要充分发挥政治优势和组织优势, 坚持高标准, 保证质量, 做好学生党员发展工作。对入党 积极分子要注重早期培养, 加强制度建设, 严格发展程序, 进行系统的党的知识教育和实践 锻炼, 发挥在民办高校学生思想政治教育中的骨干带头作用和先锋模范作用。充分发挥共青 团、学生会工作在学生中的影响力、凝聚力、号召力。

优秀的文化对大学生的思想政治水平有着潜移默化的深远影响, 环境对其的影响也发挥着举 足轻重的作用。德育环境作为校园思想文化建设的重要方面, 应该具有影响力、号召力和感 染力。因此, 我们要优化民办高校的文化氛围和教育环境, 加强校风和学风建设, 创造良好 的学习氛围; 加强校园精神文明建设, 通过物质文明的建设推动精神文明建设, 二者相辅相 成, 从而达到优秀文化对大学生思想政治觉悟的潜在影响; 在文化氛围中树立正确的人生观、 世界观、价值观, 提高学生自身的思想觉悟, 坚持以人为本的科学发展观, 坚持完善学生的 人格品质。

3. 3. 加强思想政治建设的师资力量

思想政治教育是由具体人来做的，队伍人员的构成状况，直接关系到思想政治教育效果的好 坏。民办院校思想政治队伍应该从以下几个方面进行优化 (1) 选择专业知识高, 实践能力强 的老师担任思想政治工作。（2）要求有敏锐的识别能力; 要有敏捷地思维能力, 严密的推理 能力; (3) 要有果断处理问题驾驭问题的能力。(4) 同时学历层不能单一。(5) 年龄结构应 该是老中青按一定比例相结合，民办院校的合理结构应该是中间大，两头小。这也符合目前 的民办学校实际。（6）性别结构也要男女搭配，不能单一，否则不利于性别上发挥互补效应。 教师作为优秀文化的传播者和讲授者, 是教育工作的主力军, 在对学生的学习和理解过程中 扮演者人类工程师的角色。因此, 要加强思想道德建设的专业化辅导。学校应该组建专门的 思想政治辅导队伍, 定时对导员加强专业技能培训, 提高对马克思主义理论及各种相关理论 的理解, 并且要结合时代发展和学生的自身情况, 有针对性地进行思想教育工作。同时, 要 明确导员职责，做到权责分明，对学生有针对性地提出解决方案。另外，学校应该定期组织 辅导员交流学习, 增加经验, 提高思想政治能力和实际工作能力。

3. 4. 创新完善思想政治教育机制

民办高校的思想政治教育工作是一项长期的工程, 需要学生、家长和学校三方面联合教育。 在民办高校中评选出优秀的思想政治骨干，及时发挥思想骨干对学生的师范带头作用，加强 学生的自我管理、自我约束能力, 从自身提高思想政治觉悟。其次, 随着信息化和网络化的 发展, 我们进入了互联网时代, 网络媒体也随之纳入学生的眼球。因此, 民办高校要抓住网 络时代这一契机，将思想政治教育机制与网络生活相融合，将热点新闻以课件的形式上传到 专门的网站中, 让学生提出自己的观点, 从而提高其自身对思想政治的认识。最后, 发挥家 长学校沟通责任制度, 真正实现家校沟通无障碍, 保证学生的思想政治水平的良好发展。

3. 5. 开辟学生思想政治教育新课堂, 推动思想政治教育工作新局面

(1) 学校要加强网络文化建设, 充分挖掘网上巨大的信息和教育资源, 营造全新的网络文化, 丰富和发展思想政治工作的内容。学校应大力加强学生面对信息的比较选择能力的培养。一 
方面在思想教育过程中要注意给学生提供正反兼有的全面信息, 让学生在比较中、在不同观 点的交锋中提高能力。另一方面, 应努力培养学生正确的思想方法, 提高在复杂的信息环境 中进行独立思考与分析、去伪存真的方法与能力。建立网上素质拓展学校。充分占领网络教 育这一主阵地，增强思想政治教育工作的主动性，发挥思想教育的/防患于未然的作用，而不 是充当/救火队的角色。设立网上心理等各种专题咨询室和聊天室、开设网上建议栏、公开德 育工作者的电子邮件等。帮助学生正确认识网络这一/虚拟社会 0 , 对其网络行为进行一定的 规范, 增强学生思想上的免疫力。

（2）坚持学生思想政治教育工作进公寓。辅导员进驻学生公寓，与学生同吃、同住、同生活; 把学生党团组织组建到公寓, 充分发挥党团组织引导人、团结人、凝聚人的作用; 把学生在 公寓内的表现纳入德育考评范围, 并把考评结果作为评优、评奖的重要依据; 建立学生公寓 的自我管理组织, 努力把学生公寓建成学生自我教育、自我管理、自我服务的场所; 积极开 展公寓文化建设活动, 为思想政治工作创造科学的体制和机制。加强对大学生集群行为的控 制与引导，建立正常的信息反馈和对话机制。

思想政治教育工作永远在路上。民办高校学生的思想政治教育工作, 还有许多的不足和问题, 还需进一步研究和探讨, 新的形势下, 民办高校学生思想政治工作应该随着时代的发展而不 断的创新和完善, 队伍要不断的优化和加强, 时效性和针对性应该不断的提高。因此, 民办 高校必须针对现阶段的学生的实际情况, 积累在实践中的重要经验, 不断研究和创新思想政 治教育模式, 加强大学生思想政治教育途径和方法的系统化、理论化和全面化, 充分发挥思 想政治教育的积极作用, 传播正能量, 实现民办高校学生的全面发展, 从而实现中国梦。

\section{参考文献}

[1] 光姝瑜. 新时代背景下如何加强思想政治教育 [J].教书育人(高教论坛). 2015(36):43-45

[2] 姜畅. 浅谈高校思想政治教育载体的创新[J].亚太教育. 2016(03):23-25

[3] 张智慧. 大学生思想政治教育工作面临的挑战及对策研究[J].亚太教育. 2016(03):15-17

[4] 张建红. 论作为学科与实践活动的思想政治教育 [J]. 宁夏大学学报 (人文社会科学版). 2015(06): 18-21

[5] 张砚波. 思想政治教育在高校人力资源开发中的作用[J].新西部(理论版). 2015(24):65-69

[6] 张鹏程. 大学生思想政治教育执行力研究 [J]. 贵州民族大学学报 (哲学社会科学版). 2015(05):54-57

\section{References}

[1]. Shuyu Guang. How to strengthen the Ideological and political education under the background of new era [J]. Teaching and Educating (Higher Education Forum). 2015 (36): 43-45

[2]. Chang Jiang. The innovation of Ideological and political education in the Colleges [J]. Asia Pacific Education. 2016 (03): 23-25

[3]. Zhang wisdom. Challenges and Countermeasures of Ideological and political education for college students [J]. Asia-Pacific Education. 2016 (03): 15-17

[4]. Zhihui Zhang. Ideological and political education of Subject and practice activities [J]. Journal of Ningxia University (Humanities and Social Science Edition). 2015 (06): 18-21

[5]. Yanbo Zhang. The role of Ideological and political education in the human resources development in Colleges and universities [J]. New Western (theoretical Edition). 2015 (24): 65-69

[6]. Pengcheng Zhang. Research on the executive power of Ideological and political education of 
university students [J]. Journal of Guizhou Nationalities University (Philosophy and Social Science Edition). 2015 (05): 54-57. 